Linguista: Jurnal IImiah Bahasa, Sastra, dan Pembelajarannya

Vol.3, No.2, Desember 2019, hal 69 - 79

ISSN (print): 2579-8944; ISSN (online): 2579-9037

Avaliable online at: http://e-journal.unipma.ac.id/index.php/linguista

\title{
Kajian Ekranisasi Novel "Assalamualaikum Beijing" Karya Asma Nadia dalam Bentuk Film "Assalamualaikum Beijing" Sutradara Guntur Soeharjanto
}

\author{
Widya Nur Puspitasari dan Sigit Ricahyono \\ Universitas PGRI Madiun, JI. Setiabudi No. 85, Madiun, Indonesia \\ e-mail: puspitasariwidyanur23@gmail.com; ricahyono@yahoo.com
}

\begin{abstract}
Abstrak
Penelitian ini bertujuan untuk memperoleh deskripsi tentang proses ekranisasi yang muncul pada alur, tokoh, dan latar dalam novel "Assalamualaikum Beijing" karya Asma Nadia ke bentuk film "Assalamualaikum Beijing" sutradara Guntur Soeharjanto. Metode penelitian yang digunakan adalah deskriptif komparatif. Sumber data yaitunovel "Assalamualaikum Beijing" karya Asma Nadia dan film "Assalamualaikum Beijing" sutradara Guntur Soeharjanto. Teknik pengumpulan data menggunakan dokumentasi dan pengamatan. Teknik analisis data menggunakan interactive model. Hasil penelitian menunjukkan bahwa: (1) Proses ekranisasi pada alur terdiri dari penciutan, penambahan, dan perubahan bervariasi. (2) Proses ekranisasi pada tokoh terdiri dari penciutan sebanyak 6 tokoh, penambahan sebanyak 2 tokoh, dan perubahan bervariasi. (3) Proses ekranisasi pada latar terdiri dari penciutan sebanyak 3 latar, penambahan sebanyak 5 latar tempat, dan perubahan bervariasi sebanyak 2 latar tempat dan 2 latar waktu.

Kata kunci: Ekranisasi; Alur; Tokoh; Latar.

\section{Ecranization Study on Novel "Assalamualaikum Beijing" by Asma Nadia to the Form of Movie "Assalamualaikum Beijing" Directed by Guntur Soeharjanto}

\begin{abstract}
This study aims to obtain a description of the process of ekranisasi that appears on plot, character, and setting in the novel "Assalamualaikum Beijing" by Asma Nadia to the movie "Assalamualaikum Beijing" with the director Guntur Soeharjanto. The research method used was descriptive comparative. The data sources were the novel "Assalamualaikum Beijing" by Asma Nadia and the movie "Assalamualaikum Beijing" by the director Guntur Soeharjanto. Data collection techniques were documentation and observation. The data analysis technique used was interactive models. The results show that: (1) The process of ecranization on the plot consists various of shrinking, additions, and changes. (2) The process of ecranization on figures consists of shrinking on 6 characters, adding on 2 characters, and varies on changing. (3) The process of ecranization in the setting consists of shrinking on 3 settings, adding on 5 setting of places, and various changing on 2 setting of places and 2 setting of time.
\end{abstract}

Keywords: Ecranization; Plot; Character; Setting. 


\section{Pendahuluan}

Fenomena perubahan karya sastra ke dalam bentuk film telah terjadi sejak beberapa dekade. Seger dalam Deny (2016: 151) menyatakan bahwa "Berdasarkan data statistik di tahun 1992 tercatat 85\% film pemenang Oscar merupakan adaptasi dari karya sastra (novel, cerpen, drama, dan lainnya), sementara $95 \%$ mini seri untuk televisi merupakan adaptasi dari novel, bahkan 70\% peraih Emmy Award (penghargaan terbaik untuk karya-karya di televisi) juga merupakan hasil adaptasi". Sedangkan Welsh dan Lev dalam Suwastini (2014: 829) memperkirakan bahwa sekitar 85\% film yang pernah diproduksi merupakan adaptasi dari karya sastra atau drama. Sejumlah film yang sukses, khususnya dari segi jumlah dan apresiasi penonton merupakan film yang diangkat dari karya sastra baik itu novel, cerpen, drama, dan karya sastra lainnya.

Ekranisasi merupakan bagian dari adaptasi, dimana karya sastra diubah menjadi bentuk lain seperti film atau sinetron. Proses perubahan dari karya sastra seperti novel dan cerpen menjadi film memang dibutuhkan imajinasi dalam proses pengarapannya sehingga muncul perubahan-perubahan dari peralihan novel menjadi bentuk film. Perubahan tersebut merupakan akibat dari perubahan pada alat yang dipakai, yaitu mengubah kata-kata dalam karya sastra menjadi bentuk gambar yang bergerak dalam sebuah film. Pemindahan wahana juga mempengaruhi proses perubahan, karya sastra merupakan bentuk visual yang mengarahkan pembaca untuk mengandalkan pembayangan cerita. Sedangkan film merupakan bentuk audio-visual yang memberikan gambaran cerita kepada penikmat film dengan memadukan dialog dengan ekspresi para pemain. Perubahan-perubahan tersebut akan dibandingkan oleh penonton antara adegan di film dengan novel aslinya.

Fenomena film adaptasi di Indonesia pun berkembang pesat, dimulai tahun 2000-an perfilman Indonesia semakin dibanjiri adaptasi karya sastra, baik dari novel maupun cerpen. Film adaptasi novel seperti Ca Bau Kan (Nia Dinata, 2002), Eiffel... I'm in Love (Nasry Cheppy, 2003), Gie (Riri Riza, 2005), Ayat-Ayat Cinta (Hanung Bramantyo, 2008), Ketika Cinta Bertasbih (Chaerul Umam, 2009), Dalam Mihrab Cinta (Habiburrahman El Shirazy, 2010), Sang Penari (Ifa Isfansyah, 2011), Negeri 5 Menara (Affandi Abdul Rachman, 2012), 99 Cahaya di Langit Eropa (Guntur Soeharjanto, 2013), Assalamualaikum Beijing (Guntur Soeharjanto, 2014), Surga Yang Tak Dirindukan (Kuntz Agus, 2015), Sabtu Bersama Bapak (Monty Tiwa, 2016), Critical Eleven (Monty Tiwa dan Robert Ronny, 2017), Dilan 1990 (Fajar Bustomi, 2018), dan masih banyak lagi. Sedangkan film adaptasi dari cerpen seperti Tentang Dia (Rudy Sudjarwo, 2005), Mereka Bilang, Saya Monyet (Djenar Maesa Ayu, 2007), Malaikat Juga Tahu sutradara Marcella Zalianty dari cerpen "Rectoverso" Dewi Lestari, dan masih banyak lagi.

Pemilihan kajian dan sumber data penelitian didasarkan beberapa alasan seperti: 1) Kajian ekranisasi dipilih karena telah banyak film adaptasi yang sukses mencuri perhatian penikmat film, diluar pro-kontra apabila film dibandingkan dengan novel aslinya, 2) Novel Assalamualaikum Beijing karya Asma Nadia ini merupakan karya National Best Seller, 3) Asma Nadia merupakan salah satu penulis Indonesia yang cukup produktif dan banyak karya telah diangkat ke layar kaca maupun layar lebar, dan 4) Respon masyarakat cukup bagus terhadap film adaptasi novel ini sehingga meraup jumlah penonton sebesar 560.465 dan menduduki peringkat 7 dalam top 10 film terlaris pada tahun 2014. Kajian ekranisasi pada dasarnya membahas 3 hal, yaitu: penciutan/

Linguista Vol. 3, No. 2, Desember 2019: $69-79$ 
pengurangan, penambahan, dan perubahan bervariasi pada unsur intrinsik cerita. Perubahan dalam pembuatan film memang bisa terjadi karena berbagai alasan, misalnya perubahan dilakukan jika dilihat dari sudut pandang filmis dan perubahan tersebut masih relevan dengan jalan cerita secara keseluruhan (Eneste, 191: 64-65). Oleh karena itu, penelitian ini akan mengkaji sebuah judul yaitu Kajian Ekranisasi Novel "Assalamualaikum Beijing" Karya Asma Nadia dalam Bentuk Film "Assalamualaikum Beijing" Sutradara Guntur Soeharjanto.

\section{Metode Penelitian}

Metode penelitian yang digunakan dalam penelitian ini adalah deskriptif komparatif. Sumber data yang digunakan, yaitu: novel "Assalamualaikum Beijing" karya Asma Nadia dan film "Assalamualaikum Beijing" sutradara Guntur Soeharjanto. Teknik pengumpulan data yang digunakan adalah teknik pengamatan yang digunakan saat peneliti membaca novel serta menonton film dan teknik dokumentasi untuk mengumpulkan foto yang mendukung data yang ditemukan dalam teknik pengamatan. Prosedur penelitian yang digunakan dalam penelitian ini meliputi: tahap inventarisasi data, tahap klasifikasi data, tahap analisis data, tahap pembahasan, dan tahap pelaporan. Teknik keabsahan data menggunakan triangulasi teknik dan triangulasi menggunakan bahan referensi. Sedangkan teknik analisis data dalam penelitian ini adalah interactive model.

\section{Hasil dan Pembahasan}

Hasil penelitian terbagi menjadi 3 bagian, yaitu: 1) proses ekranisasi yang muncul pada alur dalam novel dan film "Assalamualaikum Beijing". 2) proses ekranisasi yang muncul pada tokoh dalam novel dan film "Assalamualaikum Beijing". 3) proses ekranisasi yang muncul pada latar dalam novel dan film "Assalamualaikum Beijing". Setiap bagian akan diperoleh perubahan yang terjadi dalam novel "Assalamualaikum Beijing" karya Asma Nadia maupun film "Assalamualaikum Beijing" sutradara Guntur Soeharjanto.

\section{1) Proses Ekranisasi yang Muncul pada Alur}

Temuan penelitian proses ekranisasi yang muncul pada alur dalam novel "Assalamualaikum Beijing" karya Asma Nadia dan film "Assalamualaikum Beijing" sutradara Guntur Soeharjanto terdapat tiga kategorisasi, yaitu: penciutan, penambahan, dan perubahan bervariasi. Aspek alur ini terkait dengan 4 tahapan alur dalam sebuah cerita, yaitu: tahap perkenalan, tahap awal konflik, tahap puncak konflik, dantahap penyelesaian pada novel dan film "Assalamualaikum Beijing".

Kategorisasi penciutan terdapat 20 alur yang ada dalam novel tetapi tidak terdapat dalam film. Berikut ini merupakan bagian penting yang mengalami penciutan berdasarkan tahapan alur, yaitu: 1) Penciutan pada tahapan perkenalan terlihat saat Asma dan Dewa bertengkar sehingga menjadi awal pengkhianatan yang dilakukan Dewa dengan Anita, 2) Penciutan pada tahapan awal konflik terlihat saat peristiwa pengkhianatan Dewa pada Ra dengan Anita, 3) Penciutan pada tahapan puncak konflik terlihat saat Anita menyesal karena percobaan bunuh dirinya gagal bahkan Dewa tetap tidak peduli pada dia dan putrinya, dan 4) Penciutan pada tahapan penyelesaian terlihat saat Zhongwen menjadi mualaf dan terusir dari rumahnya. 
Kategorisasi penambahan terdapat 34 alur dalam film tetapi tidak terdapat dalam novel. Berikut ini merupakan adegan penting yang masuk kategorisasi penambahan berdasarkan tahapan alur, yaitu: 1) Penambahan pada tahapan perkenalan terlihat saat Asma sampai di apartemen yang dipesan Sekar dekat apartemennya, 2) Penambahan pada tahapan awal konflik terlihat saat Asma mulai merasakan sakit kepala setelah melakukan liputan di Beijing, 3) Penambahan pada tahapan puncak konflik terlihat saat Zhongwen menghampiri Asma di kantor namun Sekar yang menemui dan menyampaikan surat yang menyatakan bahwa Asma tidak bisa pergi ke Yunnan, dan 4) Penambahan pada tahapan penyelesaian terlihat saat Zhongwen membaca email balasan dari Asma yang menyuruhnya ke Indonesia.

Kategorisasi perubahan bervariasi dari novel ke film terdapat 21 perubahan alur. Berikut ini merupakan kategorisasi perubahan bervariasi yang menjadi alur penting dalam novel maupun film, yaitu:

\section{Tabel 1. Perubahan Bervariasi pada Alur}

\begin{tabular}{|c|c|c|c|}
\hline No & Bagian dalam Novel & Adegan dalam film & Tahapan Alur \\
\hline 1. & $\begin{array}{l}\text { Asma ke Beijing untuk meliput } \\
\text { sebagai tugas dari kantornya } \\
\text { yang ada di Indonesia. }\end{array}$ & $\begin{array}{l}\text { Asma ke } \text { Beijing untuk bekerja di } \\
\text { Kantor Koresponden Berita } \\
\text { Indonesia dengan Sekar. }\end{array}$ & Perkenalan \\
\hline 2. & $\begin{array}{l}\text { Asma sampai di Beijing } \\
\text { menuju penginapan (youth } \\
\text { hostel) menggunakan bis. }\end{array}$ & $\begin{array}{l}\text { Asma sampai di Beijing menuju } \\
\text { apartemen dengan dijemput Sekar } \\
\text { dan Ridwan. }\end{array}$ & Perkenalan \\
\hline 3. & $\begin{array}{l}\text { Pertemuan pertama Asma } \\
\text { dan Zhongwen terjadi saat } \\
\text { Asma sampai di Beijing dan } \\
\text { naik bis untuk menuju } \\
\text { penginapan. } \\
\text { Zhongwen meninggalkan } \\
\text { kartu namanya untuk Asma, } \\
\text { namun hilang saat turun. }\end{array}$ & $\begin{array}{l}\text { Pertemuan pertama Asma dan } \\
\text { Zhongwen saat liputan pertama } \\
\text { Asma di Beijing dan akan pulang } \\
\text { menuju apartemen. } \\
\text { Zhongwen memberikan buku kisah } \\
\text { Ashima dan berjanji akan } \\
\text { menemuinya lagi. }\end{array}$ & \multirow{3}{*}{ Konflik Awal } \\
\hline 4. & $\begin{array}{l}\text { Pertemuan kedua Asma dan } \\
\text { Zhongwen di Masjid Niujie } \\
\text { tanpa disengaja saat mereka } \\
\text { sama-sama berkunjung di } \\
\text { masjid tersebut. }\end{array}$ & $\begin{array}{l}\text { Pertemuan kedua Asma dan } \\
\text { Zhongwen di Masjid Niujie karena } \\
\text { Zhongwen menggantikan Sunny } \\
\text { sebagai Tour Guide bagi Asma. }\end{array}$ & \\
\hline 5. & $\begin{array}{l}\text { Saat Asma terkena stroke } \\
\text { pertamanya saat di Indonesia } \\
\text { bersama Mama, Sekar, dan } \\
\text { Mas Ridwan. }\end{array}$ & $\begin{array}{l}\text { Saat Asma terkena stroke } \\
\text { pertamanya posisi Asma di Beijing } \\
\text { bersama Sekar dan Mas Ridwan. }\end{array}$ & \\
\hline 6. & $\begin{array}{l}\text { Saat Zhongwen menjadi } \\
\text { mualaf, keluargan menentang } \\
\text { dan mengusirnya dari rumah. }\end{array}$ & $\begin{array}{l}\text { Saat Zhongwen menjadi mualaf } \\
\text { terjadi di Masjid Niejiu, tidak ada } \\
\text { pihak yang menentang. }\end{array}$ & \multirow{4}{*}{ Puncak Konflik } \\
\hline 7. & $\begin{array}{l}\text { Pertemuan pertama Asma } \\
\text { dan Dewa di sebuah jalan } \\
\text { setelah batal menikah. }\end{array}$ & $\begin{array}{l}\text { Pertemuan pertama setelah batal } \\
\text { menikah saat Dewa menyusul } \\
\text { Asma ke Beijing. }\end{array}$ & \\
\hline 8. & $\begin{array}{l}\text { Dokter menjelaskan penyakit } \\
\text { APS yang diderita Asma pada } \\
\text { Mama dan Sekar. }\end{array}$ & $\begin{array}{l}\text { Dokter menyampaikan penyakit } \\
\text { APS yang diderita Asma pada } \\
\text { Mama. }\end{array}$ & \\
\hline 9. & $\begin{array}{l}\text { Zhongwen dan Dewa } \\
\text { menemui Asmara dalam } \\
\text { waktu yang bersamaan } \\
\text { di rumah Ra dengan hanya } \\
\text { disaksikan Mama Asmara } \\
\text { saja. }\end{array}$ & $\begin{array}{l}\text { Zhongwen dan Dewa menemui } \\
\text { Asma disaat yang bersamaan di } \\
\text { rumah Ra dan disaksikan Mama } \\
\text { Ra, Sekar, dan Mas Ridwan. }\end{array}$ & \\
\hline 10. & $\begin{array}{l}\text { ljab kabul dan resepsi Asma } \\
\text { dan Zhongwen di Indonesia } \\
\text { dihadiri Ayah, Mama, Sekar, } \\
\text { Ridwan, dan tamu undangan. }\end{array}$ & $\begin{array}{l}\text { ljab kabul tanpa resepsi Ra dan } \\
\text { Zhongwen terjadi di Indonesia } \\
\text { dihadiri Mama, Sekar, Ridwan, dan } \\
\text { tamu undangan. }\end{array}$ & \\
\hline
\end{tabular}




\begin{tabular}{|c|c|c|c|}
\hline No & Bagian dalam Novel & Adegan dalam film & Tahapan Alur \\
\hline 11. & $\begin{array}{l}\text { Ra tinggal di Indonesia dan } \\
\text { berbulan madu di Candi } \\
\text { Borobudur, lalu Zhongwen } \\
\text { mengajaknya liburan ke } \\
\text { Beijing untuk melihat } \\
\text { bisnisnya. }\end{array}$ & $\begin{array}{l}\text { Ra dan Zhongwen tinggal di } \\
\text { Beijing bersama paman dan Bibi } \\
\text { Zhongwen untuk berobat dan } \\
\text { bekerja, serta berbulan madu di } \\
\text { Patung Ashima, Yunnan. }\end{array}$ & Penyelesaian \\
\hline 12. & $\begin{array}{l}\text { Asma dan Zhongwen memiliki } \\
2 \text { anak: "Bintang Niejiu" dan } \\
\text { "Aime Logocinta". }\end{array}$ & $\begin{array}{l}\text { Bibi hanya menyampaikan pada } \\
\text { Zhongwen dan Paman berita } \\
\text { kehamilan Asma. }\end{array}$ & \\
\hline
\end{tabular}

\section{2) Proses Ekranasi yang Muncul Pada Tokoh}

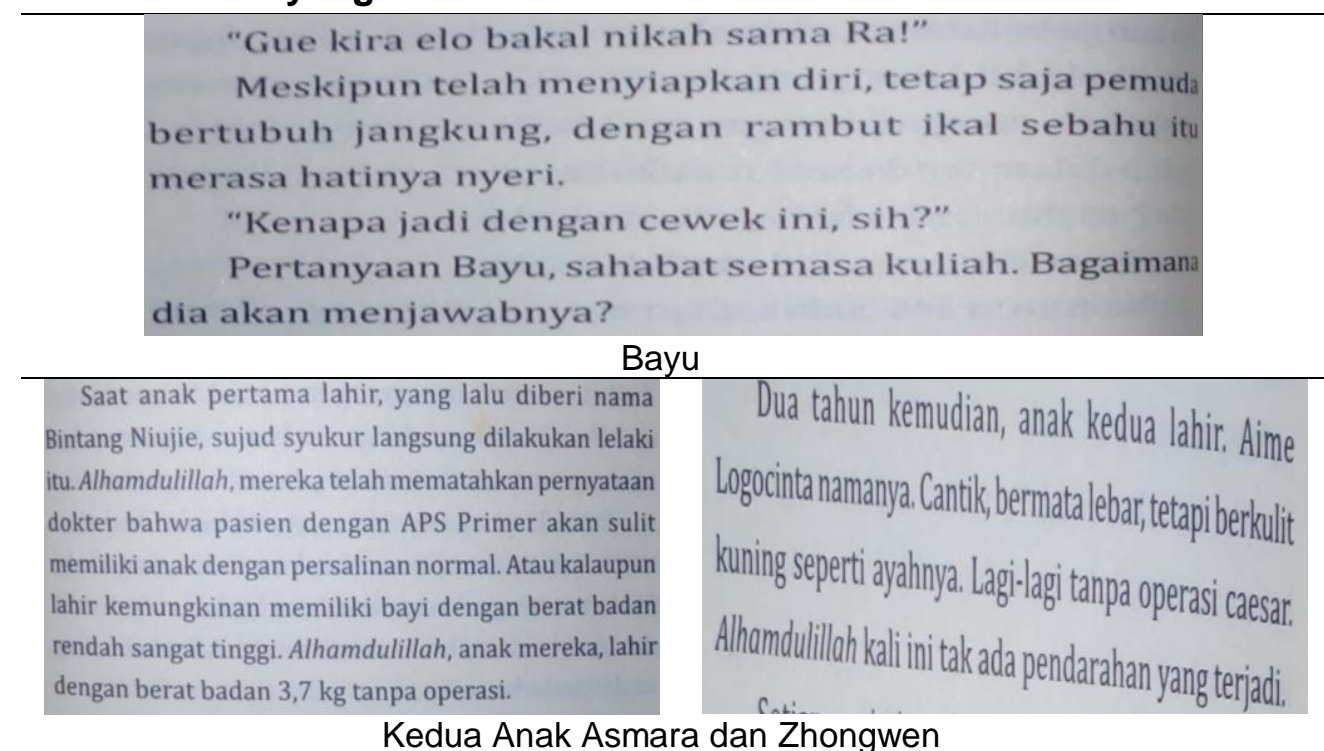

Kedua Anak Asmara dan Zhongwen

Temuan penelitian proses ekranisasi yang muncul pada tokoh dalam novel "Assalamualaikum Beijing" karya Asma Nadia dan film "Assalamualaikum Beijing" sutradara Guntur Soeharjanto terdapat tiga kategorisasi, yaitu: penciutan, penambahan, dan perubahan bervariasi. Pada kategorisasi penciutan terdapat 6 tokoh dalam novel "Assalamualaikum Beijing" karya Asma Nadia yang tidak terdapat dalam adegan film "Assalamualaikum Beijing" sutradara Guntur Soeharjanto, yaitu: Bayu, ayah Asmara, keluarga Zhongwen, ayah dan ibu Anita, Lita dan orang tua, serta kedua anak Asmara dan Zhongwen.

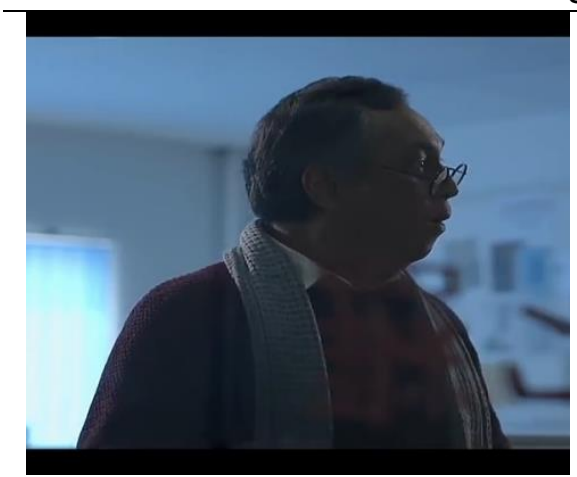

Pak Daniel

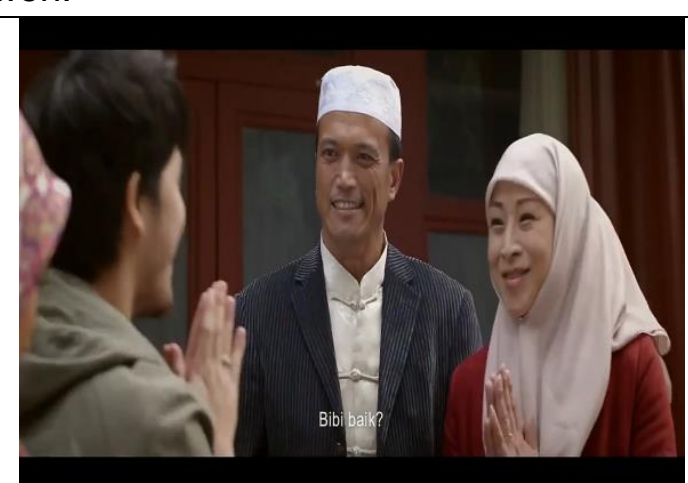

Paman dan Bibi Zhongwen

Gambar 2. Penambahan pada Tokoh 
Kategorisasi penambahan terdapat 2 tokoh yang terdapat dalam film "Assalamualaikum Beijing" sutradara Guntur Soeharjanto tetapi tidak terdapat dalam novel "Assalamualaikum Beijing" karya Asma Nadia, yaitu: Pak Daniel serta paman dan bibi Zhongwen. Kategorisasi perubahan bervariasi terdapat 4 perubahan pada tokoh dalam novel "Assalamualaikum Beijing" karya Asma Nadia ke film "Assalamualaikum Beijing" sutradara Guntur Soeharjanto, yaitu:

a. Perubahan pada penampilan Zhongwen yang menggunakan tas ransel dalam novel menjadi tas slempang dalam film.

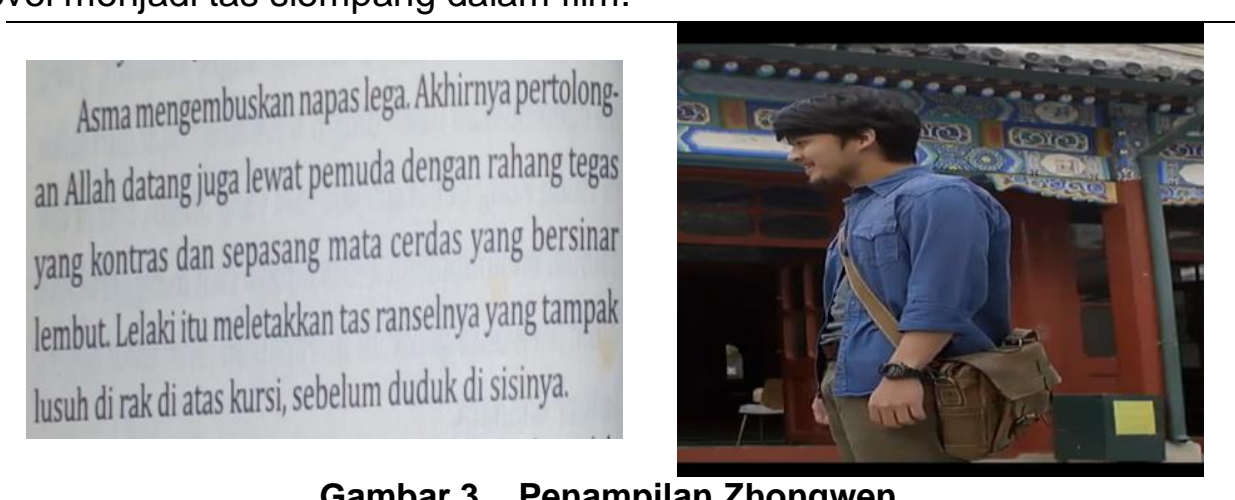

Gambar 3. Penampilan Zhongwen

b. Perubahan pada pekerjaan Zhongwen yang merupakan pemilik Biro Travel di Xi'an dalam novel menjadi Tour Guide dalam film.

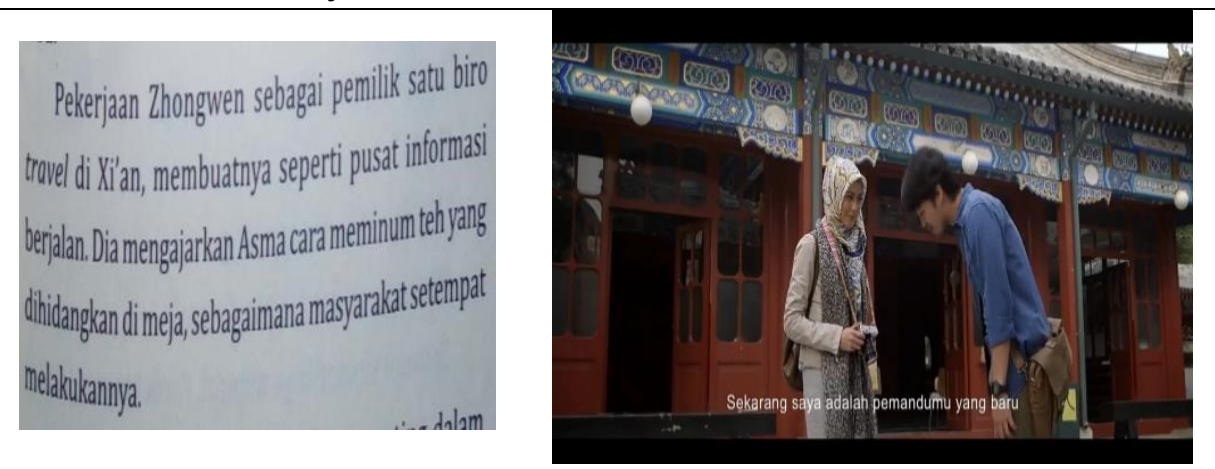

Gambar 4. Pekerjaan Zhongwen

c. Perubahan pada penampilan Dewa yang berambut gondrong dalam novel menjadi beramput pendek dan rapi dalam film.

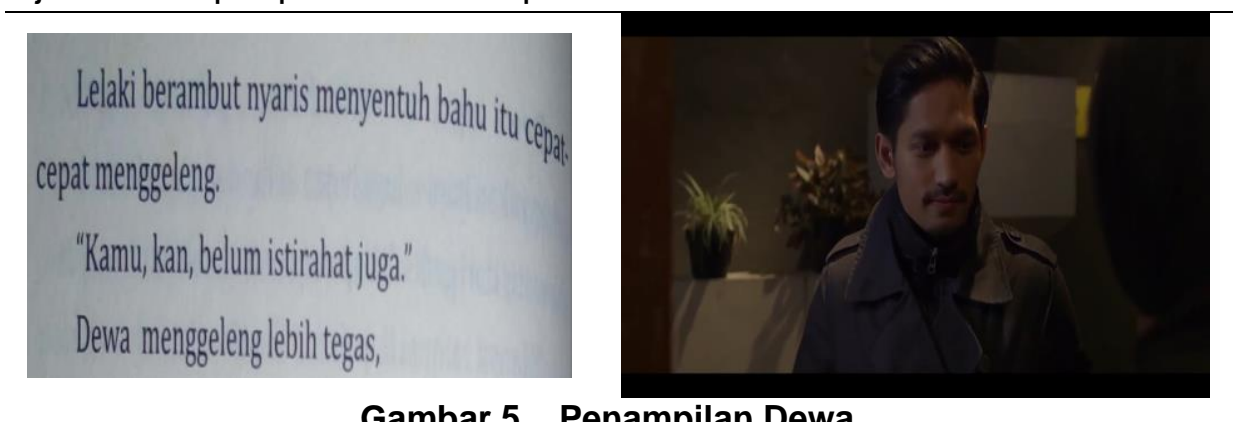

Gambar 5. Penampilan Dewa 
d. Perubahan pada penampilan Sunny (Tour Guide) yang berkaca mata dalam novel menjadi tidak berkaca mata dan bermata sipit

Menurut gadis berkacamata itu, lebih baik tak
membawa banyak beban saat menaiki satu demi satu
anak tangga.
Awalnya, Asma,yang merasa sehat dan terbilang kuat
jalan, ingin menolak. Ini bukan traveling pertamanya.
Banyak tujuan wisata yang mensyaratkan stamina.
Namun, Sunny terus bersikeras.

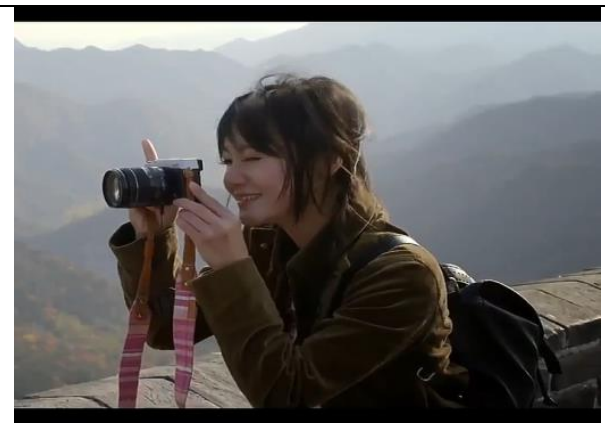

Gambar 6. Penampilan Sunny

3) Proses Ekranisasi yang Muncul pada Latar

\begin{tabular}{cc}
\hline Bayangan Ashima-nya terlihat di mana-mana. Di & $\begin{array}{c}\text { Langit biru hanya dihiasi sedikit awan ketika mereka } \\
\text { tiba di pelataran candi. } \\
\text { Direrumputan, tak begitu jauh dari area Borobudur, } \\
\text { langit-langit rumah, dinding kamar, dapur dan berbagail } \\
\text { keduanya duduk beralaskan tikar sambil memandang } \\
\text { bangunan megah berbentuk punden yang terdiri dari } \\
\text { sepuluh tingkat. Asma menyandarkan tubuhnya pada } \\
\text { bahu Zhongwen yang tegak kukuh. } \\
\text { Ada } 1.460 \text { relief, } 504 \text { stupa. Dibangun tiga abad } \\
\text { tulus. Dan, hal-hal sederhana dengan mudah akan } \\
\text { membelum Angkor Wat di Kamboja dan empat abad } \\
\text { sebelum kehadiran Katedral Agung di Eropa. Salah satu } \\
\text { kebanggan terbesar rakyat Indonesia. } \\
\text { Zhonowan pada kenangan. Pertemuan singkat } \\
\text { Candi Borobudur, Yogyakarta }\end{array}$ \\
\hline
\end{tabular}

\section{Gambar 7. Penciutan pada Latar}

Temuan penelitian proses ekranisasi yang muncul pada latar novel dan film "Assalamualaikum Beijing" terdapat tiga kategorisasi, yaitu: penciutan, penambahan, dan perubahan bervariasi. Proses ekranisasi pada latar ini berupa penciutan dan penambahan latar tempat serta perubahan bervariasi pada latar tempat dan waktu dari novel "Assalamualaikum Beijing" karya Asma Nadia menjadi film "Assalamualaikum Beijing" sutradara Guntur Soeharjanto.Kategorisasi penciutan terdapat 3 latar tempat dalam novel yang tidak terdapat dalam adegan film, yaitu: Tiananmen Square dan The Forbidden City, rumah Zhongwen, dan Candi Borobudur di Yogyakarta.

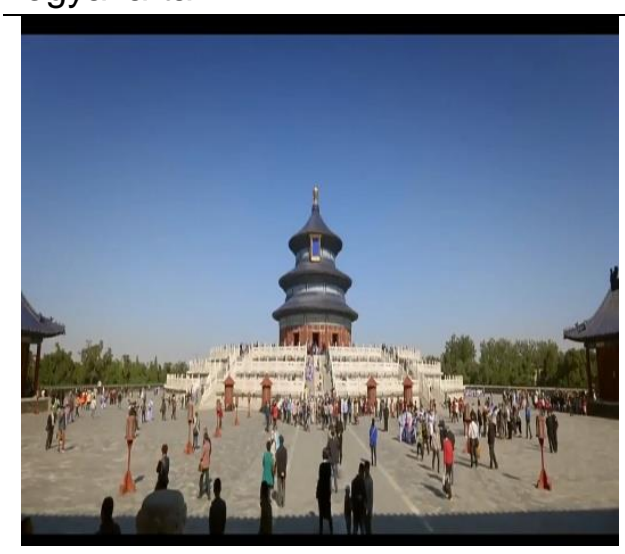

Temple of Heaven

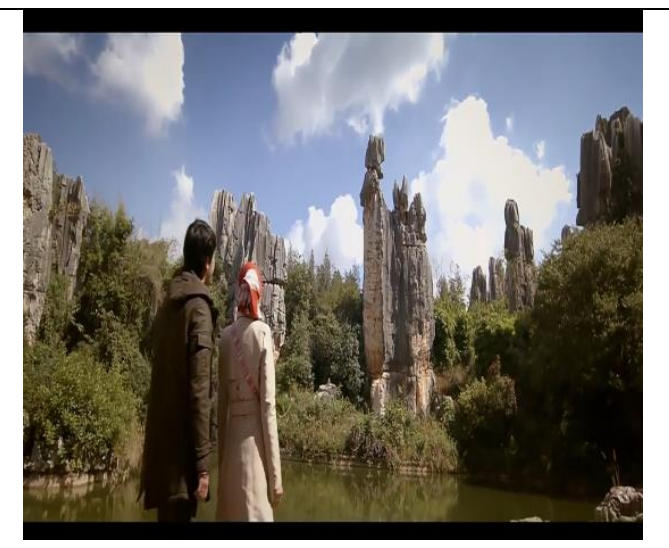

Patung Ashima, Yunnan 


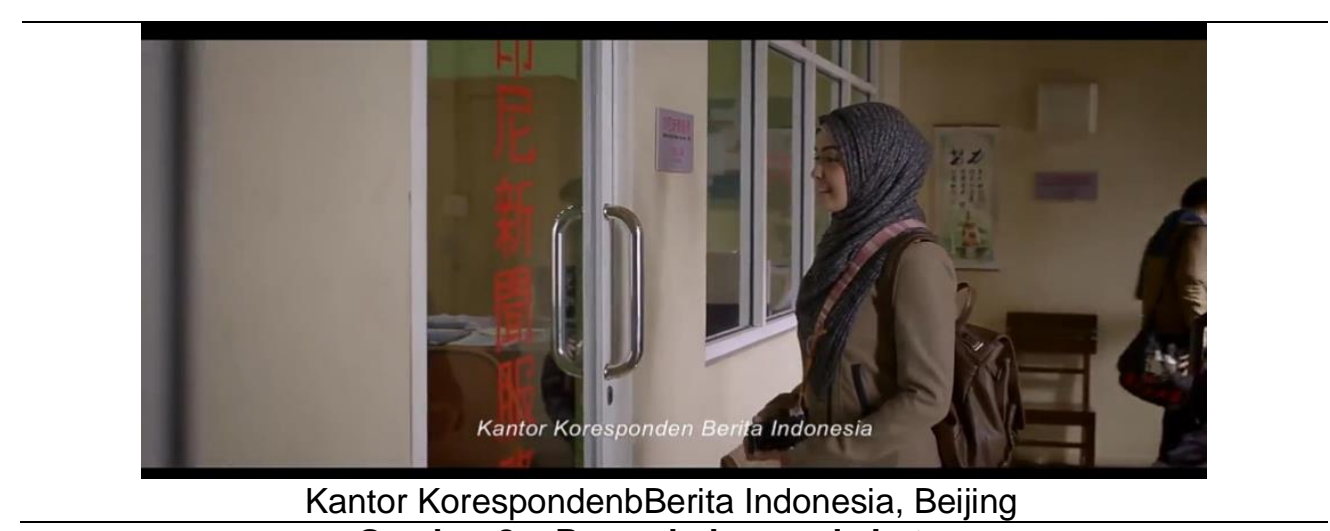

Gambar 8. Penambahan pada Latar

Kategorisasi penambahan terdapat 5 latar tempat yang terdapat dalam film tetapi tidak terdapat dalam novel, yaitu: Kantor Koresponden Berita Indonesia di Beijing, Toko (pemilik muslim) di Beijing, Temple of Heaven (Kuil Bumi dan Langit), rumah Paman dan Bibi Zhongwen di Beijing, dan Patung Ashima di Yunnan.Pada kategorisasi perubahan bervariasi terdapat 4 perubahan pada latar tempat dan waktu dalam novel ke film, yaitu:

a. Perubahan tempat saat Dewa jujur pada Ra tentang pengkhianatan yang dilakukannya di Halte dalam novel menjadi di Halaman Rumah Ra dalam film.

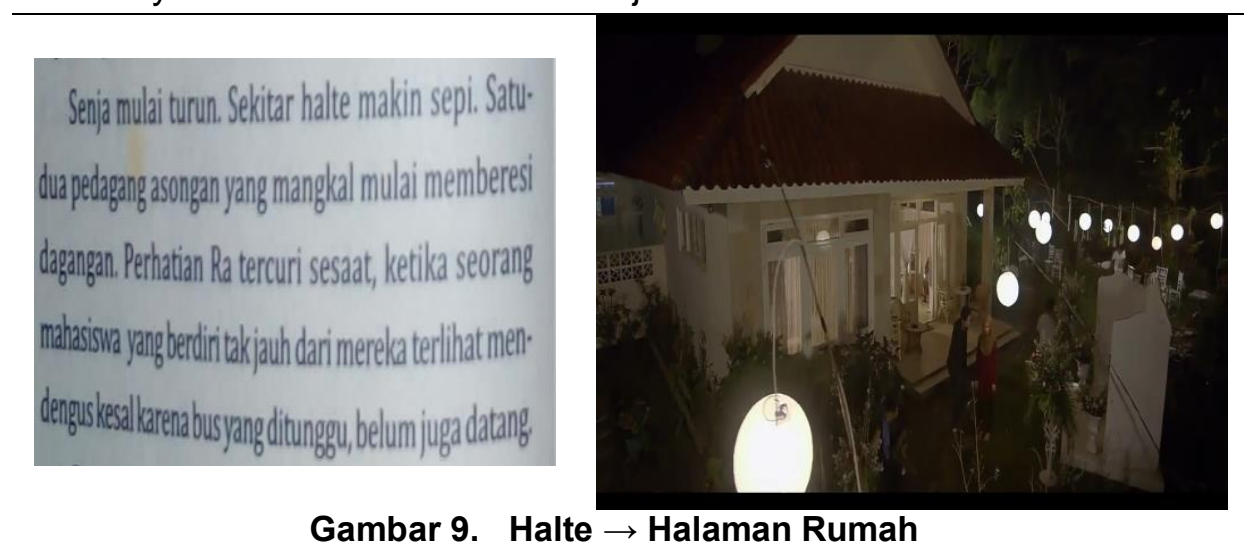

b. Perubahan waktu saat Dewa jujur pada Ra tentang pengkhianatan yang dilakukannya saat senja dalam novel menjadi malam dalam film.
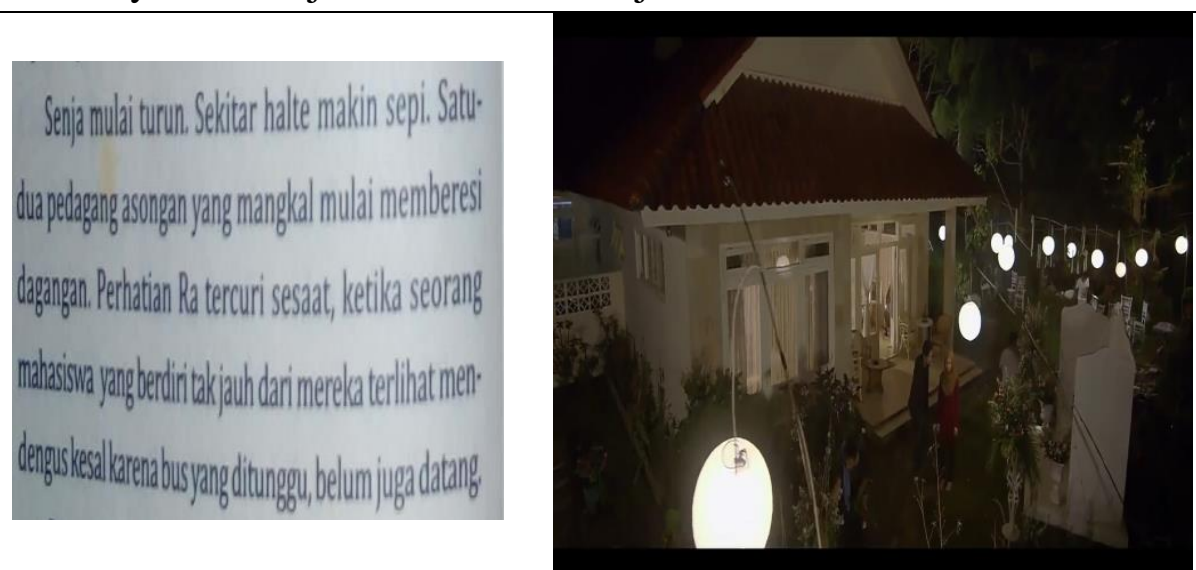

Gambar 10. Senja $\rightarrow$ Malam 
c. Perubahan waktu saat Ra tiba di bandara Hongkong saat malam hari dalam novel menjadi pagi hari dalam film.

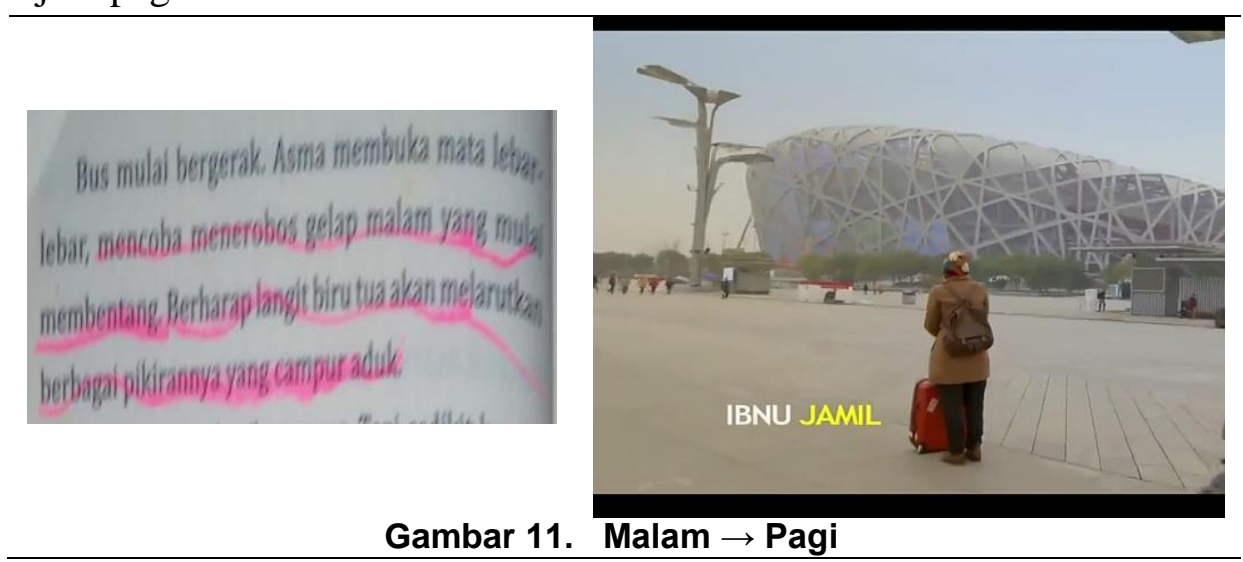

d. Perubahan tempat tinggal Asmara selama di Beijing dari penginapan (Youth Hostel) dalam novel menjadi Apartemen dalam film.
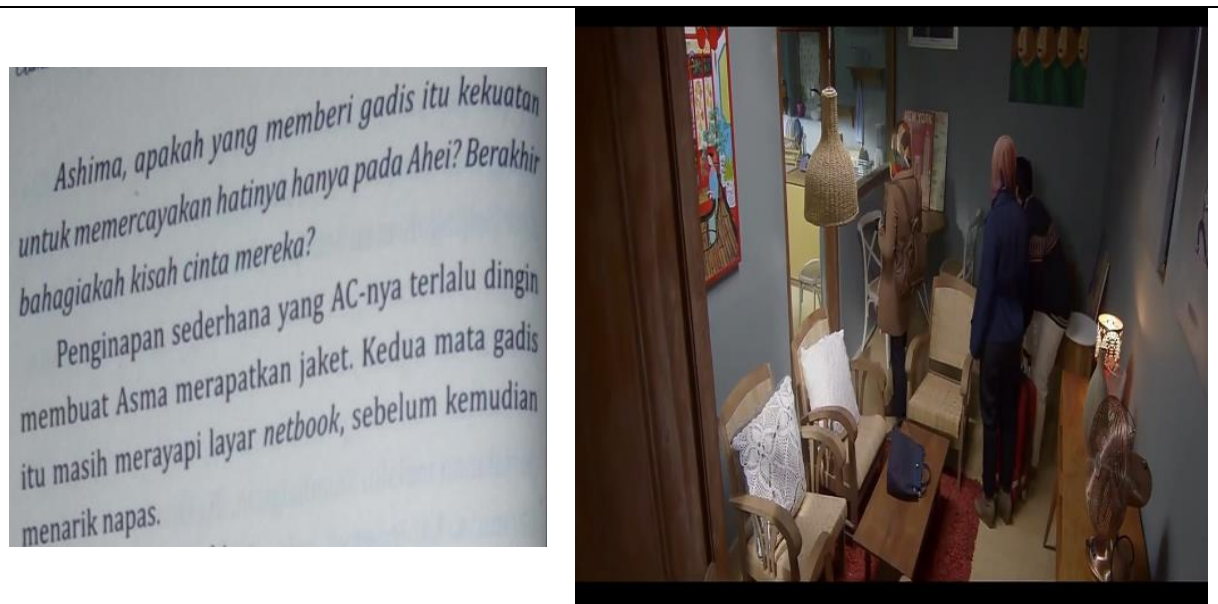

Gambar 12. Penginapan (Youth Hostel) $\rightarrow$ Apartemen

Setelah paparan temuan penelitian diatas, maka dapat disimpulkan bahwa proses ekranisasi yang muncul pada alur, tokoh, dan latar meliputi penciutan, penambahan, serta perubahan bervariasi.Hal ini sejalan dengan teori yang dikemukakan Pamusuk Eneste (1991) pada bukunya yang berjudul "Novel dan Film", dimana Eneste menyatakan bahwa dalam proses ekranisasi akan terjadi perubahan berupa penciutan, penambahan, dan perubahan bervariasi pada unsur-unsur cerita.Hasil penelitian ini sejalan dengan penelitian yang dilakukan Carmila., Mursalim., \& Rokhmansyah (2018) yang berjudul "Transformasi Novel Sabtu Bersama Bapak Karya Aditya Mulya Menjadi Film Sabtu Bersama Bapak Karya Monty Tiwa: Kajian Ekranisasi”. Mereka menyatakan bahwa proses ekranisasi yang muncul pada alur, tokoh, dan latar meliputi penciutan, penambahan, dan perubahan bervariasi. Teori dan hasil penelitian tersebuttidak sejalan dengan penelitian yang dilakukan Praharwati \& Romadhon (2017) yang berjudul "Ekranisasi Sastra: Apresiasi Penikmat Sastra Alih Wahana". Dalam penelitian tersebut dipaparkan bahwa proses ekranisasi meliputi persamaan, perbedaan, dan penambahan adegan. Sehingga dilihat dari istilah yang dipakai, penelitian tersebut mengarah pada sumber data film saja. Berbeda dengan istilah yang dipakai dalam penelitian ini dan sejalan dengan 
teori yang dikemukakan Pamusuk Eneste, maka penelitian ini mengarah pada proses membandingkan novel dan film sehingga data ditemukan bukan hanya berupa adegan dalam film melainkan juga pada bagian novelyang mengalami perubahan.

Proses ekranisasi yang muncul pada alur dalam penelitian ini meliputi penciutan, penambahan, dan perubahan bervariasi. Penelitian ini sejalan dengan penelitian yang dilakukan oleh Martin (2017) yang berjudul "Ekranisasi Novel Yang Tak Dirindukan Karya Asma Nadia ke Film Surga Yang Tak Dirindukan Karya Sutradara Kuntz Agus", dimana proses ekranisasi yang muncul pada alur terdiri atas penciutan, penambahan, dan perubahan bervariasi. Walaupun jika dilihat dari data penelitian, terlihat berbeda karena pembagian alur tidak berdasarkan tahapan alur. Hal tersebut juga didukung dengan penelitian yang dilakukan Oktafiyani., Suseno., \& Nuryantin (2017) dengan judul "Transformasi Makna Simbolik Mihrab pada Novel ke Film Dalam Mihrab Cinta Karya Habiburrahman El Shirazy: Kajian Ekranisasi” dan Isnaniah (2015) yang berjudul "Ketika Cinta BertasbihTransformasi Novel ke Film". Penelitian ini tidak sejalan dengan penelitian yang dilakukan Praharwati \& Romadhon (2017) yang berjudul "Ekranisasi Sastra: Apresiasi Penikmat Sastra Alih Wahana". Dalam penelitian tersebut dipaparkan bahwa perubahan bervariasi pada alur hanya didukung foto adegan dalam film, tidak ada perbandingan dengan perubahan bagian novelnya. Sehingga kevalidan data masih diragukan, berbeda dengan penelitian ini yang menampilkan perubahan dari novel ke filmnya.

Proses ekranisasi yang muncul pada tokoh dalam penelitian ini meliputi penciutan, penambahan, dan perubahan bervariasi. Penelitian ini sejalan dengan penelitian yang dilakukan oleh Armiati (2018) yang berjudul "Ekranisasi Novel Assalamualaikum Beijing Ke Dalam Film Assalamualaikum Beijing", dimana proses ekranisasi yang muncul pada tokoh terdiri atas penciutan dan penambahan.Perbedaandengan penelitian ini terletak pada tidak muncul perubahan bervariasi. Sejalan dengan penelitian Armiati, penelitian yang dilakukan Karkono (2009) yang berjudul "Perbedaan Makna Novel dan Film Ayat-Ayat Cinta: Kajian Ekranisasi", hanya muncul perubahan bervariasi saja pada tokoh. Penelitian Karkono didukung oleh penelitian Martin (2017)yang berjudul "Ekranisasi Novel Yang Tak Dirindukan Karya Asma Nadia ke Film Surga Yang Tak Dirindukan Karya Sutradara Kuntz Agus" dan penelitian yang dilakukan Isnaniah (2015) yang berjudul "Ketika Cinta Bertasbih Transformasi Novel ke Film". Keduanya menyatakan bahwa hanya perubahan bervariasi yang muncul pada tokoh.

Proses ekranisasi yang muncul pada latar dalam penelitian ini meliputi penciutan, penambahan, dan perubahan bervariasi.Penelitian ini beberapa sejalan dengan penelitian yang dilakukan oleh Armiati (2018) yang berjudul "Ekranisasi Novel Assalamualaikum Beijing Ke Dalam Film Assalamualaikum Beijing", dimana proses ekranisasi yang muncul pada latar terdiri atas perubahan bervariasi saja. Perubahan bervariasi terletak pada latar tempat, waktu, dan sosial. Sedangkan menurut Isnaniah (2015) dalam penelitiannya yang berjudul "Ketika Cinta Bertasbih Transformasi Novel ke Film" menyatakan bahwa pada aspek latar hanya muncul penciutan dan perubahan bervariasi. Pernelitian Armiati juga didukung penelitian yang dilakukan oleh Martin (2017) yang berjudul "Ekranisasi Novel Yang Tak Dirindukan Karya Asma Nadia ke Film Surga Yang Tak Dirindukan Karya Sutradara Kuntz Agus”, dimana hanya perubahan bervariasi saja yang muncul pada aspek latar. Sehinggadari 
penelitian-penelitian sebelumnya, bisa disimpulkan bahwa hasil penelitian ini cukup lengkap karena muncul semua proses ekranisasi berupa penciutan, penambahan, serta perubahan bervariasi pada aspek latar baik waktu maupun tempat.

\section{Kesimpulan}

Berdasarkan hasil penelitian dan pembahasan diatas, maka dapat disimpulkan bahwa: 1) Proses ekranisasi yang muncul pada alur novel dan film "Assalamualaikum Beijing" meliputi penciutan, penambahan, dan perubahan bervariasi. 2) Proses ekranisasi yang muncul pada tokoh novel dan film "Assalamualaikum Beijing" meliputi penciutan, penambahan, dan perubahan bervariasi. 3) Proses ekranisasi yang muncul pada latar novel dan film "Assalamualaikum Beijing" meliputi penciutan, penambahan, dan perubahanbervariasi. Perubahan bervariasi pada aspek latar berupa latar waktu dan tempat. Selain itu, penelitian ini banyak memiliki perbedaan dengan penelitian sebelumnya. Perbedaannya terletak pada pengumpulan dan analisis, dimana dalam penelitian ini penciutan dan penambahan dipaparkan secara mendalam berdasarkan bagian dalam novel serta adegan dalam film. Sedangkan pada perubahan bervariasi terlihat perubahan karena didukung dengan foto bagian dalam novel yang dibandingkan dengan adegan dalam film. Perubahan-perubahan tersebut tidak terlepas pada struktur teks yang digunakan peneliti saat pengumpulan data sehingga kevalidan dapat dipastikan dalam hasil penelitian ini.

\section{Daftar Pustaka}

Ardianto, D. T. (2016). Teori Adaptasi Sebuah Pendekatan dalam Penciptaan Film. MUDRA: Jurnal Seni Budaya, 31(2): 150-251.

Armiati, Y. (2018). Ekranisasi Novel Assalamualaikum Beijing Ke Dalam Film Assalamualaikum Beijing. Master Bahasa, 6(3): 301-310.

Carmila, S. D., Mursalim., \& Rohkmansyah, A. (2018). Transformasi Novel Sabtu Bersama Bapak Karya Aditya Mulya Menjadi Film Sabtu Bersama Bapak Karya Monty Tiwa: Kajian Ekranisasi. Jurnal Ilmu Budaya, 2(4): 381-388.

Eneste, P. (1991). Novel dan Film. Flores: Nusa Indah.

Isnaniah, S. (2015). Ketika Cinta Bertasbih Transformasi Novel Ke Film. KAWISTARA, 5(1): 1-98.

Karkono, K. (2009). Perbedaan Makna Novel dan Film Ayat-Ayat Cinta: Kajian Ekranisasi. ATAVISME, 12(2): 167-180.

Martin, M. (2017). Ekranisasi Novel Surga Yang Tak Dirindukan Karya Asma Nadia Ke Film Surga Yang Tak Dirindukan Karya Sutradara Kuntz Agus. Jurnal KATA, 1(1): 94-100.

Oktafiyani, A., Suseno, \& Nuryanti, A. (2017). Transformasi Makna Simbolik Mihrab pada Novel ke Film dalam Mihrab Cinta Karya Habiburrahman El Shirazy: Kajian Ekranisasi. Jurnal Sastra Indonesia, 6(3): 39-45.

Praharwati, D. W., \& Romadhon, S. (2017). Ekranisasi Sastra: Apresiasi Penikmat Sastra Alih Wahana. Buletin Al-Turas, XXIII (2): 267-285.

Suwastini, N. K. A. (2014). In/fidelity Criticism: Menuju Kajian Adaptasi yang Lebih Kritis dan Terbuka. Seminar Nasional Riset Inovatif, ISSN: 2339-1553, 829-842. 